\title{
Effect factors of terrestrial acidification in Brazil for use in Life Cycle Impact Assessment
}

\section{Crespo-Mendes, Natalia; Laurent, Alexis; Hauschild, Michael Zwicky}

\section{Published in:}

International Journal of Life Cycle Assessment

Link to article, DOI:

$10.1007 / \mathrm{s} 11367-018-1560-7$

Publication date:

2019

Document Version

Peer reviewed version

Link back to DTU Orbit

Citation (APA):

Crespo-Mendes, N., Laurent, A., \& Hauschild, M. Z. (2019). Effect factors of terrestrial acidification in Brazil for use in Life Cycle Impact Assessment. International Journal of Life Cycle Assessment, 24(6), 1105-1117. https://doi.org/10.1007/s11367-018-1560-7

\section{General rights}

Copyright and moral rights for the publications made accessible in the public portal are retained by the authors and/or other copyright owners and it is a condition of accessing publications that users recognise and abide by the legal requirements associated with these rights.

- Users may download and print one copy of any publication from the public portal for the purpose of private study or research.

- You may not further distribute the material or use it for any profit-making activity or commercial gain

- You may freely distribute the URL identifying the publication in the public portal 


\title{
Effect factors of terrestrial acidification in Brazil for use in Life Cycle Impact Assessment
}

\author{
Natalia Crespo-Mendes*, Alexis Laurent and Michael Zwicky Hauschild \\ Division for Quantitative Sustainability Assessment (QSA), Department of Management \\ Engineering, Technical University of Denmark (DTU), 2800 Kgs. Lyngby, Denmark \\ * To whom correspondence should be addressed; e-mail: ncme@dtu.dk
}

\begin{abstract}
Purpose: In Life Cycle Impact Assessment, atmospheric fate factors, soil exposure factors and effect factors are combined to characterize potential impacts of acidifying substances in terrestrial environments. Due to the low availability of global datasets, effect factors (EFs) have been reported as the major contributors to statistical uncertainties of characterization factors and they are the focus of this study. We aim to develop spatially differentiated EFs taking Brazil as case, and explore new methodological ways to derive them.

Methods: EFs are calculated based on a comprehensive database reporting observations of approximately 30000 plant species at biome and ecoregion levels. Species richness distributions as function of soil $\mathrm{pH}$ are developed and translated into Potentially Not Occurring Fraction (PNOF) of species, which can be equated to the more commonly-used Potentially Disappeared Fraction of species, to assess effects of changes in soil hydrogen ion concentration on terrestrial plant species. Potentially Extinct Fraction (PXF) of species is proposed as a complementary metric for LCIA models based on distributions of rangerestricted species (species only occurring in one ecoregion of Brazil). Different approaches for determining EFs from the species richness distributions are evaluated. Area-weighted EFs are explored to determine potential effects when considering both acid and alkaline sides of species richness curves, thus integrating potentially positive effects of acidification on biodiversity.
\end{abstract}

Results and discussion: Spatially differentiated EFs are provided for 6 biomes and 45 ecoregions composing Brazil. Comparisons with previous EFs demonstrate that data availability might significantly influence regression analyses and the use of more 
representative data can lead to more consistent EFs. Moreover, consideration of the entire species richness curves yields positive and negative EFs. Adding acidifying substances onto specific soils in Brazilian ecoregions may therefore be associated with increased species richness if the $\mathrm{pH}$ approaches the optimum $\mathrm{pH}$ from the alkaline side of the curve. The meaningfulness of species richness as indicator of acidification stress is discussed based on this finding, as is the inclusion of the metric PXF, highlighting species whose loss could cause irreversible damages to the environment.

Conclusions: We recommend the calculation of area-weighted EFs to be integrated into characterization models for terrestrial acidification, and we therefore advocate that similar work be done for other regions in the world than Brazil to enhance the consistency of the EFs and reduce their uncertainties. We additionally recommend that LCIA method developers further explore the application of PXF for other impact categories than acidification.

Keywords: Species richness, Endemism, Extinction, Biodiversity loss, Biome, Ecoregion.

\section{INTRODUCTION}

As an impact category in Life Cycle Impact Assessment (LCIA), terrestrial acidification is primarily caused by the atmospheric emissions and depositions of nitrogen oxides (NOx), sulfur dioxide $\left(\mathrm{SO}_{2}\right)$ and ammonia $\left(\mathrm{NH}_{3}\right)$ (EC-JRC 2010). To characterize the potential impacts that these acidifying substances can cause in the environment, the LCIA methodologies rely on characterization factors (CF), which are generally composed of an atmospheric fate factor (FF), an exposure factor (XF) and an effect factor (EF) (Udo de Haes et al. 2002). Existing CF calculated at midpoint level are usually given by the FF or its combination with the XF. They can express the potential acidification impacts in terms of hydrogen ions $\left(\mathrm{H}^{+}\right)$released into the environment (as in CML 1992 (Heijungs et al. 1992), EDIP 97 (Wenzel et al. 1997; Hauschild and Wenzel 1998) and MEEuP (Kemna et al. 2005) LCIA methodologies), $\mathrm{H}^{+}$ions deposited on land (as in TRACI (Norris 2003), EPS (Steen 1999) and LIME (Hayashi et al. 2004) methodologies), relative risk ratio (CML 2002, Guinee et al. (2002)), affected ecosystem areas due to exposure over its critical load, in which the ecosystem sensitivity is considered but not in terms of species loss (EDIP 2003 (Potting et al. 1998) methodology), accumulative critical load exceedance (Accumulated Exceedance, Seppälä et al. 2006) methodology) or soil acidity change (ReCiPe (Van Zelm et al. 2007; Goedkoop et al. 2009) (Van Zelm et al. 2015). The EF are included in the calculations and 
the CF can express the potential damages to the ecosystem through net primary productivity (LIME methodology, Hayashi et al. 2004) or occurrences of plants species, which can address damages to all plant species (ReCiPe 2016 (Huijbregts et al. 2017), Impact World+ (2018) and LC-Impact (2018) methodologies) or to specific target plant species (Ecoindicator 99 methodology) (Van Zelm et al. 2015).

According to the guidance for LCIA in the European context offered by the International Reference Life Cycle Data System (ILCD) Handbook (EC-JRC 2011), among the evaluated endpoint methodologies for acidification there is a lack of global fate models and effect models for other continents than Europe. The ILCD Handbook however does not address the recent developments with LCIA methods like Impact World+ (2018), LC-Impact (2018) and ReCiPe 2016 (Huijbregts et al. 2017), that bring advances regarding spatial differentiation and provide spatially differentiated characterization factors on a global scale. These methodologies adopt the same models for the calculations of fate factor (Roy et al. 2012a), exposure factor (Roy et al. 2012b) and effect factor (Azevedo et al. 2013; Roy et al. 2014). While the fate factor and, to a lesser extent, the exposure factor have been reported to be the main source of spatial variability, the effect factors have been identified as the main source of statistical uncertainties of the characterization factors due to the low availability of global data sets (Roy et al. 2014; Van Zelm et al. 2015). In Azevedo et al. (2013) spatially-resolved EFs are calculated based on the relationships between changes in plant species richness and soil $\mathrm{pH}$ variations, taking occurrences of 2409 plant species worldwide attributed to 13 terrestrial global biomes. Considering the species diversity in a country like Brazil, which has more than 30000 species of plants (Forzza et al. 2012; Crespo-Mendes et al. 2018), one may question the representativeness of the EF calculated in Azevedo et al. (2013) and Roy et al. (2014), thus calling for more comprehensive studies.

In this study, taking Brazil as a case study, we therefore aim to (1) provide updated spatially differentiated EFs for terrestrial acidification in Brazil, based on the use of a comprehensive botanic database and investigate their spatial variability (ecoregion, biome and whole country levels); (2) assess the influence of data completeness and representativeness, and increased spatial resolution, on EF values by comparing the obtained EFs with those developed in recent LCIA methodologies; and (3) discuss the appropriateness of the metrics used in LCIA to address biodiversity loss caused by acidification. The selection of Brazil was motivated by 
the extensive territorial area and great variations in terms of population density, anthropogenic activities and environmental characteristics throughout the country.

\section{METHODS}

\subsection{Data sources}

\subsubsection{Botanical data}

A comprehensive and harmonized data inventory of terrestrial plants in Brazil reported by Crespo-Mendes et al. (2018) was used to estimate the potential losses of terrestrial plants species richness as a result of exposure to acidifying substances. Data were collected based on records provided by the Global Biodiversity Information Facility (GBIF 2017) and processed by using the Geographic Information System (GIS) into a georeferenced inventory of 29712 terrestrial plant species with a harmonized nomenclature. The number of different species observed in a certain region, defining the region's species richness, was quantified for the six biomes and 47 ecoregions in Brazil delineated by Olson et al. (2001) (see Figure 1). Further details on the construction of the plant species inventories are available in CrespoMendes et al. (2018).

(a)

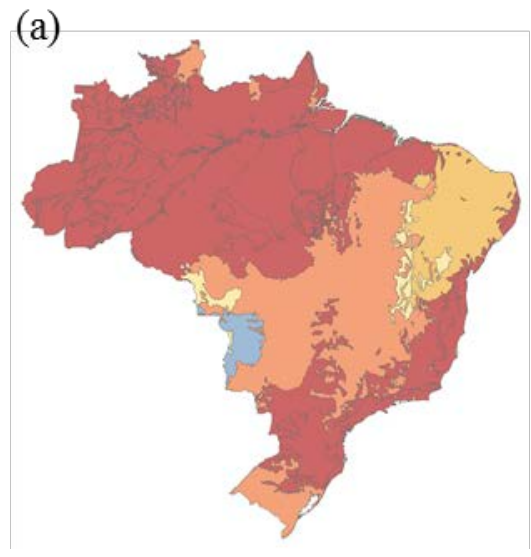

(b)

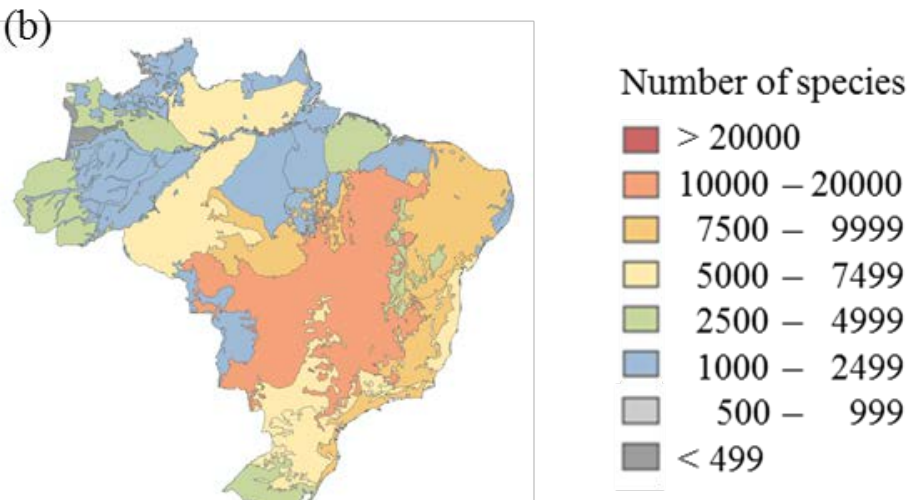

Figure 1. Terrestrial plant species in Brazil: (a) per biome (six biomes) and (b) per ecoregion (47 ecoregions) (from Crespo-Mendes et al., 2018). 


\subsection{2. $\mathrm{pH}$ data}

Soil $\mathrm{pH}$ was taken as an indicator of soil acidity. The $\mathrm{pH}$ data used in this study were extracted for each unit of 1-km² grid cells from SoilGrids1 km (Hengl et al. 2014) and processed to represent a depth range of $0-60 \mathrm{~cm}$, which was assumed relevant for plant root exposure to acidifying or alkalizing substances. Figure 2 presents the soil $\mathrm{pH}$ distribution in Brazil. Details are provided in Crespo-Mendes et al. (2018).

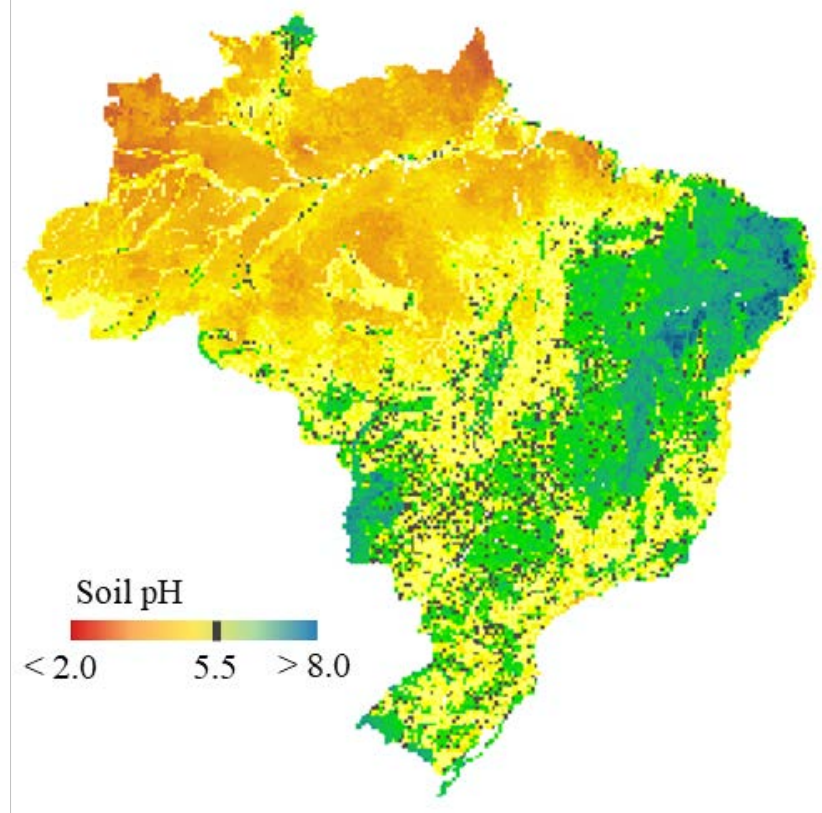

Figure 2. Soil pH distribution in Brazil: acidic soil in Brazil corresponds to $67 \%$ of the country area $(\mathrm{pH}<5.5$, in yellow-red), $27 \%$ of the country area are non-acidic soil $(\mathrm{pH}>5.5$, in green-blue) and $6 \%$ of the area is considered neutral area $(\mathrm{pH}=5.5$, in black) (from CrespoMendes et al., 2018)

\subsubsection{Species richness distribution data}

Data about species richness distributions as function of the soil $\mathrm{pH}$ at country, biome and ecoregion levels were reported in Crespo-Mendes et al. (2018). The distributions were obtained by matching the georeferenced locations of terrestrial plant species (Section 2.1.1) with their associated soil $\mathrm{pH}$ values (Section 2.1.2) and by assigning to each species a range of soil $\mathrm{pH}$ defined by the lowest and highest $\mathrm{pH}$ values at which the species has been recorded. Even though a species has not been recorded for all intermediate $\mathrm{pH}$ values and 
may also exist (unobserved) outside the determined range, the thus determined soil $\mathrm{pH}$ range was assumed to be representative of the occurrence of the species due to the high number of observations reported in the plant inventory (Crespo-Mendes et al. 2018).

\subsection{Potentially Not Occurring Fraction (PNOF)}

The Potentially Not Occurring Fraction (PNOF) of species is a zero-to-one measure representing the presence or absence of species (Equation 1) used for determining the effect factors (Azevedo et al. 2013) (see Section 2.3). It is an alternative metric to the more commonly-used Potentially Disappeared Fraction (PDF) of species, as it focuses on the fraction of species that potentially do not occur, i.e. potential losses of species in a given region due to changes in soil $\mathrm{pH}$. To be consistently integrated within the LCIA methodologies, PNOF can be converted to PDF through equalization of PNOF in PDF $(\mathrm{PNOF}=\mathrm{PDF})(\mathrm{LC}-$ Impact, 2018; Huijbregts et al. 2017). Note that the PDF provided in this

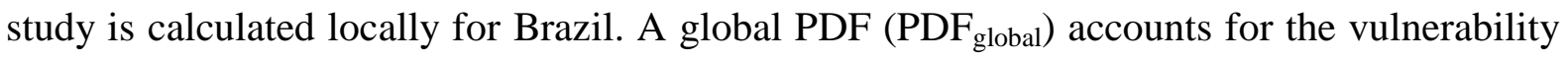
of the species, reflecting that not all species are equally affected depending on their adaptive capacity and recovery potential. The $\mathrm{PDF}_{\text {global, }}$ which combines the actual species richness with vulnerability scores (VS), has been used to assess biodiversity effects from land and water use within LCIA (Verones et al. 2015) and should ideally be sought in future works that extend this study.

The species richness distributions obtained in Section 2.1.3 were translated into modeled PNOF by using lognormal regression analysis (Equation 2). A lognormal distribution was considered since it showed a slightly better fit to the collected data than a logistic distribution, with $\mathrm{R}^{2}$ values of 0.999 for entire Brazil, $\mathrm{R}^{2}>0.955$ for all six biomes and $\mathrm{R}^{2}$ values of 0.830-1.000 for 40 out of 45 ecoregions (two additional ecoregions could not be described by the regression model; data not shown) (Crespo-Mendes et al. 2018). The lognormal regression fit also made it easier to capture both sides of the species richness curve (termed "SR curve" in the following), where the optimum $\mathrm{pH}$ (i.e. the $\mathrm{pH}$ value at which the highest species richness occurs within a region) was taken as a boundary between acid $\left(\mathrm{pH}<\mathrm{pH}_{\mathrm{opt}}\right)$ and alkaline $\left(\mathrm{pH}>\mathrm{pH}_{\mathrm{opt}}\right)$ sides of the curve. Thus, this approach also shows potential effects on plant species richness by decreasing soil $\mathrm{pH}$ towards the optimum $\mathrm{pH}$ from the alkaline side of the SR curve. To the authors' knowledge, such possible environmental mechanism 
has not been addressed in any of the previous studies with regard to acidification although positive effects have been included in assessment of other impact categories, like water stress (e.g. Scherer and Pfister 2016).

$$
P N O F_{i j}=1-\frac{S R_{i j}}{S R_{\max j}}
$$

where $\mathrm{SR}_{\mathrm{ij}}$ is the predicted value of species richness present at $\mathrm{pH} i$ in biome or ecoregion $j$, and $\mathrm{SR}_{\max , \mathrm{j}}$ is the highest species richness occurring at any $\mathrm{pH}$ value in the biome or ecoregion $j$.

$$
S R_{i j}=\frac{a}{C} \exp \left[-0.5\left(\frac{\ln \left(C / x_{0}\right)}{b}\right)^{2}\right]
$$

where $\mathrm{C}$ is the soil concentration of $\mathrm{H}^{+}\left[\mathrm{mol} \mathrm{H}^{+}\right.$. $\mathrm{L}^{-1}$ ] relative to the $\mathrm{SR}_{\mathrm{ij}}$ and $\mathrm{a}, \mathrm{b}$ and $\mathrm{x}_{0}$ are regression parameters derived from the lognormal distribution model. Associated $\mathrm{R}^{2}$ values and regression coefficients are given in Table S1, Electronic Supplementary Material, ESM.

\subsection{Potentially Extinct Fraction (PXF)}

Following the approach used for modeling the Potentially Not Occurring Fraction (PNOF) of all species (see Section 2.2), the Potentially Extinct Fraction (PXF) of species is a zero-to-one measure representing the presence or absence of range-restricted species. We propose this new metrics based on previous works having focused on endemic species in other impact categories (e.g. de Baan et al. 2013; Verones et al. 2013). Here, PXF were modeled based on the selection of plant species that were found to occur in only one of Brazil's ecoregions (i.e. range-restricted species). Some of them may also occur outside Brazil and thus not be truly endemic to the ecoregion, but due to the size of the country and its high species diversity, many of the thus defined range-restricted species will be truly endemic (Crespo-Mendes et al. 2018). Decreasing the species richness of range-restricted plant species thus indicates the potential extinction of unique species. 
Although both PXF and $\mathrm{PDF}_{\text {global }}$ (see Section 2.2; Verones et al. 2015) aim to reflect a differentiation of species - trying to emphasize those species most likely to be extinct - PXF only includes the range-restricted species and thus omits all other species, which may be functionally-important for the ecosystems. Unlike PXF, in a global PDF this information could still be retained and included. Ideally, extending to a global scale the procedures for collecting and processing data on species occurrence and soil $\mathrm{pH}$ would allow the calculation of $\mathrm{PDF}_{\text {global }}$ and the comparison between the list of range-restricted species and endemic species to the world. However, it requires important computational resources, which could not be met in this work.

\subsection{Effect factors (EF)}

Effect factors (EF) were calculated based on the state-of-the-art characterization models for terrestrial acidification (Azevedo et al. 2013; Roy et al. 2014), which is the approach adopted by Impact World+ (2018), LC-Impact (2018) and ReCiPe 2016 (Huijbregts et al. 2017) methodologies. The effect factors express the effect on the plant species occurrence from a change in soil hydrogen ion concentration. They were defined by the slope of the SR curve (see Section 2.1.3) at the relevant soil $\mathrm{pH}$ value, which was translated into PNOF (Section 2.2) or PXF (Section 2.3) by the integration of Equation 2 into Equation 1 (see Section 2.2), thus, the derivative was calculated as a function of $\mathrm{C}$ (soil concentration of $\mathrm{H}^{+}\left[\mathrm{mol} \mathrm{H}^{+}\right.$. $\left.\mathrm{L}^{-1}\right]$ ) as described by Equation 3.

$$
E F_{i j}=\frac{d P N O F_{i j}}{d C}=\frac{\left(1-P N O F_{i j}\right)}{C} \cdot\left[1+\frac{\ln \left(C / x_{0}\right)}{b^{2}}\right]
$$

We used different settings to enable the calculation of EFs for biomes and ecoregions and the comparison with the existing factors. Table 1 gives an overview of the settings used for the calculations. To show the potential differences with previous studies due to the use of different species occurrence data sets, the EFs were first calculated using logistic regression distributions (Table 1, sets $1 \mathrm{a}$ and $1 \mathrm{~b}$ ) to be compatible with the EFs calculated from Roy et 
al. (2014) (Table 1, set 2) and Azevedo et al. (2013) (Table 1, set 3). Effect factors calculated in Azevedo et al. (2013) and Roy et al. (2014) are based on the same plant inventory reported in Azevedo et al. (2013) but adopt different approaches to relate species richness to soil pH. Roy et al. (2014) bases the pH-dependent species richness distributions on the lowest $\mathrm{pH}$ at which each species was recorded (termed " $\mathrm{pH}$ min" approach in the following) while Azevedo et al. (2013) considers the whole interval defined by the lowest and highest pH value at which each species was recorded (termed " $\mathrm{pH}$ range” approach). Both approaches base the calculation of EFs on the $\mathrm{pH}$ value where $50 \%$ of plant species potentially do not occur (PNOF $=0.5$ ), which is similar to the approach applied in the calculation of effect factors for ecotoxicity based on a species sensitivity distribution curve representing the potentially affected fraction (PAF) of species as a function of the toxicant concentration (Larsen and Hauschild 2007; Pennington et al. 2004).

Acidification impacts on vegetation differ mechanistically from impacts caused by toxic chemicals and the analogy with ecotoxicological effects may be inadequate for estimating impacts caused by acidifying substances as illustrated by the bell-shaped form of the PNOF curves. In order to analyze the behavior of species throughout their entire distribution curves, we also applied a pH range approach and propose as an alternative calculation of EF the areaweighted $\mathrm{EF}\left(\mathrm{EF}_{\mathrm{aw}}\right) . \mathrm{EF}_{\mathrm{aw}}$ is defined as the weighted average of the $\mathrm{EF}$ for each $\mathrm{pH}$ unit, using as weighting factor the area that each $\mathrm{pH}$ unit represents relative to the total area of the studied region (e.g. ecoregion or biome) (Equation 4). Sets 4a and 4b allow the comparison between an EF calculated based on PNOF $=0.5$ and an area-weighted EF for the acid and alkaline sides of the SR curves separately, at country, biome and ecoregion levels. Additionally, sets $5 \mathrm{a}$ and $5 \mathrm{~b}$ allow the comparison between area-weighted $\mathrm{EF}\left(\mathrm{EF}_{\mathrm{aw}}\right)$ calculated from the complete list of plant species and on the list of range-restricted species, at country, biome and ecoregions levels.

$$
E F_{a w}=\sum \frac{E F_{i j} \cdot A_{i j}}{A_{t o t j}}
$$

where $\mathrm{EF}_{\mathrm{ij}}$ and $\mathrm{A}_{\mathrm{ij}}$ are, respectively, the $\mathrm{EF}$ and the area $\left(\mathrm{km}^{2}\right)$ for each $\mathrm{pH}$ unit $i$ in biome or ecoregion $j$, and $\mathrm{A}_{\text {tot } \mathrm{j}}$ is the total area $\left(\mathrm{km}^{2}\right)$ of biome or ecoregion $j$. 
Table 1. Settings for effect factor calculations.

\begin{tabular}{|c|c|c|c|c|c|c|c|}
\hline Set & Appro & & $\begin{array}{l}\text { Curve } \\
\text { side }\end{array}$ & Regression & Resolution & Data set & Data source \\
\hline $\begin{array}{l}1 \mathrm{a} \\
1 \mathrm{~b}\end{array}$ & $\mathrm{PNOF}=0.5$ & $\begin{array}{l}\text { pH min. } \\
\text { pH range }\end{array}$ & Acid & Logistic & Biome & All species & $\begin{array}{l}\text { Crespo-Mendes } \\
\text { et al. (2018) }\end{array}$ \\
\hline 2 & $\mathrm{PNOF}=0.5$ & $\mathrm{pH}$ min. & Acid & Logistic & Biome & All species & $\begin{array}{l}\text { Roy et al. } \\
(2014)^{\mathrm{a}}\end{array}$ \\
\hline 3 & $\mathrm{PNOF}=0.5$ & pH range & Acid & Logistic & Biome & All species & $\begin{array}{l}\text { Azevedo et al. } \\
(2013)^{\mathrm{a}}\end{array}$ \\
\hline $\begin{array}{l}4 a \\
4 b\end{array}$ & $\begin{array}{l}\text { PNOF }=0.5 \\
\text { Area-weighted }\end{array}$ & pH range & $\begin{array}{l}\text { Acid / } \\
\text { Alkaline }\end{array}$ & Lognormal & $\begin{array}{l}\text { Biome/ } \\
\text { Ecoregion }\end{array}$ & All species / & $\begin{array}{l}\text { Crespo-Mendes } \\
\text { et al. (2018) }\end{array}$ \\
\hline $\begin{array}{l}5 a \\
5 b\end{array}$ & Area-weighted & $\mathrm{pH}$ range & $\begin{array}{l}\text { Entire } \\
\text { curve }\end{array}$ & Lognormal & $\begin{array}{l}\text { Biome/ } \\
\text { Ecoregion }\end{array}$ & $\begin{array}{l}\text { All species } \\
\text { Range-restricted } \\
\text { species }\end{array}$ & $\begin{array}{l}\text { Crespo-Mendes } \\
\text { et al. (2018) }\end{array}$ \\
\hline
\end{tabular}

\section{RESULTS AND DISCUSSION}

\subsection{Influence of more comprehensive data set}

Table 2 shows the comparison of EFs based on different datasets, using previous approaches for calculations (see Table 1). As previously described, scenarios 1a and 2 refer to the species count based on $\mathrm{pH}$ min (Roy et al. 2014), i.e. the lowest $\mathrm{pH}$ where each species occurs in a given biome, while scenarios $1 \mathrm{~b}$ and 3 use the $\mathrm{pH}$ range defined by the lowest and highest $\mathrm{pH}$ value at which each species occurs in a given biome (Azevedo et al. 2013). The ratios between our EF and the existing factors presented in Table 2 show significant discrepancies for the 6 biomes, ranging from 0.07 to 9.27 for the EF calculated from the $\mathrm{pH}$ range approach and from 0.06 to 75.13 for the EF based on the minimum pH (comparison of set 1a vs. 2 and 1b vs. 3; see Table 2). Some consistency can be observed where our study yields higher EFs (for the biomes Tropical and subtropical moist broadleaf forests and Mangroves) or considerably lower EF (Deserts and xeric shrublands) compared to both previous studies. For 
two biomes (Tropical and subtropical grasslands, savannas and shrublands, and Flooded grasslands and savannas) the difference is more inconsistent, with Roy et al. (2014) > The current study > Azevedo et al. (2013), and for the last biome (Tropical and subtropical dry broadleaf forests) the current study gives much higher EF than Roy et al. (2014) while Azevedo et al. (2013) do not report any value.

The applied database is the primary difference between the three scenarios and hence the cause of differences between the EFs. The EFs by Azevedo et al. (2013) and by Roy et al. (2014) were based on data collected from a critical review of the scientific literature (reported by Azevedo et al., 2013). Although the critical review may result in more accurate $\mathrm{pH}$ values for the species at a given location, this eventually limited the number of studies addressed to determine the species richness and soil pH per biome (i.e. 140 studies listing a total of 2409 plant species worldwide). In addition, the data available in Azevedo et al., 2013 represent the number of species per biomes distributed throughout the world, without possibility of differentiating data specifically referring to the Brazilian territory. In our study we considered compiled information from separate databases of plant occurrences and soil $\mathrm{pH}$ in Brazil, combined using the Geographic Information System (GIS). The higher representativeness of the data set (an inventory of 29712 plants species) is evident when comparing the number of species per biome and the number of species at the optimum $\mathrm{pH}$ between the three studies. For example, the number of species covered by Azevedo et al. (2013) for the biome Deserts and xeric shrublands is approximately $5 \%$ of the number of species reported in the current study (Crespo-Mendes et al. 2018), and for the remaining biomes this number decreases to 12\% (see Table 3), thus indicating a very low coverage of species in Azevedo et al. (2013). Table 3 also shows the $\mathrm{pH}$ range of species occurrence. The study by Azevedo et al. (2013) with lowest number of species reports maximum $\mathrm{pH}$ values of species occurrence higher than those observed in Crespo-Mendes et al. (2018) for 4 out of 6 biomes (see Table 3). The broader $\mathrm{pH}$ range does not guarantee that the highest values of $\mathrm{pH}$ are related to soils of Brazil, since the data set reported by Azevedo et al. (2013) covers biomes on a global scale without the differentiation of specific data for Brazil. The reported high $\mathrm{pH}$ values of species occurrence may thus relate to soils in other countries than Brazil, where the same biomes are represented. The differences shown in terms of ratios between EFs (Table 2) result from the use of a more comprehensive and representative data set, demonstrating that the much lower number of reported plant species (see Table 3), which yielded lower species richness, greatly influences the determined EF. 
Table 2. Effect factors at $\mathrm{PNOF}=0.5$ [PNOF. $\left.\left(\mathrm{mol} \mathrm{H}^{+} . \mathrm{L}^{-1}\right)^{-1}\right]$ : comparison with previous approaches at the biome level (sets 1a, 1b, 2 and 3).

\begin{tabular}{|c|c|c|c|c|c|c|}
\hline \multirow[b]{2}{*}{ Biome } & \multicolumn{3}{|c|}{ (pH min) } & \multicolumn{3}{|c|}{ (pH range) } \\
\hline & $\begin{array}{l}\text { This study } \\
{[\text { PNOF.(mol }} \\
\left.\left.\mathrm{H}^{+} \cdot \mathrm{L}^{-1}\right)^{-1}\right] \\
\\
\text { (set 1a) }\end{array}$ & 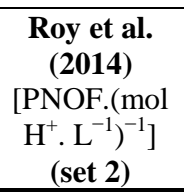 & $\begin{array}{l}\text { This study/ } \\
\text { Roy et al. } \\
\text { (2014) }\end{array}$ & $\begin{array}{c}\text { This study } \\
{[\text { PNOF.(mol }} \\
\left.\left.\mathrm{H}^{+} . \mathrm{L}^{-1}\right)^{-1}\right] \\
\text { (set 1b) }\end{array}$ & $\begin{array}{c}\text { Azevedo et } \\
\text { al. (2013) } \\
{[\text { PNOF.(mol }} \\
\left.\left.\mathrm{H}^{+} . \mathrm{L}^{-1}\right)^{-1}\right] \\
\text { (set 3) }\end{array}$ & $\begin{array}{l}\text { This study/ } \\
\text { Azevedo et } \\
\text { al. (2013) }\end{array}$ \\
\hline $\begin{array}{l}\text { Tropical and subtropical } \\
\text { moist broadleaf forests }\end{array}$ & $1.43 \mathrm{E}+04$ & $2.00 \mathrm{E}+03$ & 7.16 & $1.12 \mathrm{E}+04$ & $2.14 \mathrm{E}+03$ & 5.23 \\
\hline $\begin{array}{l}\text { Tropical and subtropical } \\
\text { dry broadleaf forests }\end{array}$ & $1.61 \mathrm{E}+05$ & $2.14 \mathrm{E}+03$ & 75.13 & $1.72 \mathrm{E}+05$ & - & - \\
\hline $\begin{array}{l}\text { Tropical and subtropical } \\
\text { grasslands, savannas and } \\
\text { shrublands }\end{array}$ & $6.62 \mathrm{E}+04$ & $8.33 \mathrm{E}+04$ & 0.80 & $6.25 E+04$ & $2.41 \mathrm{E}+04$ & 2.60 \\
\hline $\begin{array}{l}\text { Flooded grasslands and } \\
\text { savannas }\end{array}$ & $2.37 \mathrm{E}+05$ & $2.45 \mathrm{E}+06$ & 0.10 & $2.56 \mathrm{E}+05$ & $6.72 \mathrm{E}+04$ & 3.80 \\
\hline $\begin{array}{l}\text { Deserts and xeric } \\
\text { shrublands }\end{array}$ & $1.39 \mathrm{E}+05$ & $2.31 \mathrm{E}+06$ & 0.06 & $1.18 \mathrm{E}+05$ & $1.74 \mathrm{E}+06$ & 0.07 \\
\hline Mangroves & $3.61 \mathrm{E}+04$ & $5.03 \mathrm{E}+03$ & 7.18 & $2.11 \mathrm{E}+04$ & $2.28 \mathrm{E}+03$ & 9.27 \\
\hline
\end{tabular}

Table 3. Overview of plant species richness data for each stuy.

\begin{tabular}{|c|c|c|c|c|c|c|}
\hline \multirow[t]{2}{*}{ Biome } & \multicolumn{3}{|c|}{$\begin{array}{l}\text { Azevedo et al. (2013) and Roy et al. } \\
\text { (2014) (data extracted from Azevedo } \\
\text { et al. } 2013 \text { for both studies) }\end{array}$} & \multicolumn{3}{|c|}{$\begin{array}{l}\text { This Study (data extracted from } \\
\text { Crespo-Mendes et al. 2018) }\end{array}$} \\
\hline & $\begin{array}{l}\text { Number } \\
\text { of } \\
\text { species }\end{array}$ & $\begin{array}{l}\text { Number of } \\
\text { species at the } \\
\text { optimum pH }\end{array}$ & $\begin{array}{l}\mathrm{pH} \text { range } \\
\text { of species } \\
\text { occurrence }\end{array}$ & $\begin{array}{l}\text { Number } \\
\text { of } \\
\text { species }\end{array}$ & $\begin{array}{l}\text { Number of } \\
\text { species at the } \\
\text { optimum pH }\end{array}$ & $\begin{array}{l}\mathrm{pH} \text { range } \\
\text { of species } \\
\text { occurrence }\end{array}$ \\
\hline $\begin{array}{l}\text { Tropical and subtropical } \\
\text { moist broadleaf forests }\end{array}$ & 533 & 358 & $3.0-8.2$ & 25774 & 16399 & 2.4-7.9 \\
\hline $\begin{array}{l}\text { Tropical and subtropical } \\
\text { dry broadleaf forests }\end{array}$ & 139 & 65 & 5.5-8.5 & 5656 & 2879 & 4.1-7.7 \\
\hline $\begin{array}{l}\text { Tropical and subtropical } \\
\text { grasslands, savannas and } \\
\text { shrublands }\end{array}$ & 131 & 107 & $4.5-6.1$ & 16172 & 9764 & $3.5-7.6$ \\
\hline $\begin{array}{l}\text { Flooded grasslands and } \\
\text { savannas }\end{array}$ & 18 & 18 & 5.3-6.9 & 1965 & 1038 & 4.4-7.8 \\
\hline $\begin{array}{l}\text { Deserts and xeric } \\
\text { shrublands }\end{array}$ & 350 & 293 & 5.1-10.5 & 7505 & 4835 & $3.7-8.3$ \\
\hline Mangroves & 25 & 25 & $3.4-7.2$ & 3268 & 1184 & $3.5-7.0$ \\
\hline
\end{tabular}


Mendes N.C., Laurent A., Hauschild M.Z., 2018. Effect factors of terrestrial acidification in Brazil for use in Life Cycle Impact Assessment. International J ournal of Life Cycle Assessment. https://doi.org/10.1007/s11367-018-1560-7.

${ }^{a}$ Data extracted from Azevedo et al. (2013) represent the number of species per biomes distributed throughout the world, whereas data extracted from Crespo-Mendes et al. (2018) represent the number of species per biomes within Brazil.

\subsection{Integrating both acid and alkaline sides of the SR curves}

Table 4 shows calculated EFs for terrestrial acidification at country and biome levels in Brazil. The EFs were calculated with the settings presented in sets $4 a, 4 b, 5 a$ and $5 b$, as reported in Table 1 (see Section 2.4). Analyzing the acid and alkaline sides of the SR curve, two soil $\mathrm{pH}$ values are obtained corresponding to $\mathrm{PNOF}=0.5$ instead of only one - when considering the acid part of the distribution curve only, as done in previous studies by Azevedo et al. (2013) and Roy et al. (2014). Positive values for EFs are obtained when considering $\mathrm{pH}$ values on the acid side of the SR curve. For the alkaline side, negative EF values are obtained (see Table 4) meaning that adding acidity to a soil on the alkaline side of the optimum $\mathrm{pH}$ will be associated with an increase in species richness as $\mathrm{pH}$ approaches the optimum $\mathrm{pH}$ from the right side of the curve. In this context, decreasing soil $\mathrm{pH}$ may not necessarily be associated with damages to the environment, depending on the soil $\mathrm{pH}$ where the acidifying substance is deposited. Increasing spatial differentiation helps to better capture the specificities in this regard. Using EFs calculated on the basis of ecoregions in Brazil can better capture the disparities between ecoregions that belong to the same biome, which is discussed in Section 3.4.

The previous models for terrestrial acidification (Azevedo et al. 2013; Roy et al. 2014) focus on the acid side of the SR curve and define EFs based on PNOF $=0.5$, i.e. where $50 \%$ of plant species potentially do not occur. This is inspired by the approach that is currently taken in ecotoxicity effect modelling (Pennington et al. 2004; Larsen and Hauschild 2007) to represent the impact of a toxic substance on the occurrence of species in the exposed ecosystem. Protons from acidification are thus treated in the same way as a toxic agent, but this approach ignores the bell shape of the species richness distributions and PNOF with an optimum $\mathrm{pH}$ value in terms of species richness meaning that addition of acidity may be associated with a higher species diversity as well as a lower one. The probability of either of the two may be represented by the fraction of areas within the region that have soil $\mathrm{pH}$ on either side of the optimum $\mathrm{pH}$, thus reinforcing the relevance of area-integrated EF. Moreover, it is assumed that the larger the area of land with a certain soil $\mathrm{pH}$, the greater the probability of this area to receive acidifying substances. Thus, as long as species richness is 
the basis of the indicator for ecosystem damage, the area-weighted effect factors $\left(\mathrm{EF}_{\mathrm{aw}}\right)$ considering both sides of the curve should be preferred in calculation of EF for acidification since they reflect (i) how the acidifying emissions move the region away from or towards the optimum soil $\mathrm{pH}$, and (ii) the contribution of each area of land with a specific $\mathrm{pH}$ value within a region. Adopting this approach implies the possibility of obtaining negative characterization factors to be applied in the LCA studies. 
Mendes N.C., Laurent A., Hauschild M.Z., 2018. Effect factors of terrestrial acidification in Brazil for use in Life Cycle Impact Assessment. International J ournal of Life Cycle Assessment. https://doi.org/10.1007/s11367-018-1560-7.

Table 4. Effect factors for terrestrial acidification per biome and for total Brazil, for all species [PNOF. $\left(\mathrm{mol} \mathrm{H}^{+} \text {. } \mathrm{L}^{-1}\right)^{-1}$ ] and range-restricted species [PXF.(mol H+ $\left.\mathrm{L}^{-1}\right)^{-1}$ ]. Between parentheses the EFs with uncertainty ranges (EFs calculated considering the 95\% confidence interval on the SR curves).

\begin{tabular}{|c|c|c|c|c|c|c|}
\hline \multirow[t]{2}{*}{ Biome } & \multicolumn{2}{|c|}{$\begin{array}{c}\text { EF } \\
{\left[\text { PNOF. }\left(\mathrm{mol} \mathrm{H}^{+} . \mathrm{L}^{-1}\right)^{-1}\right]} \\
(\mathbf{P N O F}=\mathbf{0 . 5})\end{array}$} & \multicolumn{3}{|c|}{$\begin{array}{c}\mathbf{E F}_{\text {aw }} \\
{\left[\text { PNOF. }\left(\mathrm{mol} \mathrm{H}^{+} . \mathrm{L}^{-1}\right)^{-1}\right]} \\
\text { (area-weighted) }\end{array}$} & \multirow{2}{*}{$\begin{array}{c}\mathbf{E F}_{\text {aw-rr }} \\
{\left[\text { PXF. }\left(\mathrm{mol} \mathrm{H}^{+} \cdot \mathrm{L}^{-1}\right)^{-1}\right]} \\
\text { (range-restricted) } \\
\text { Entire curve } \\
\text { (set } 5 \mathbf{b}) \\
\end{array}$} \\
\hline & $\begin{array}{l}\text { Acid side } \\
\text { (set 4a) } \\
\end{array}$ & $\begin{array}{c}\text { Alkaline side } \\
\text { (set 4a) } \\
\end{array}$ & $\begin{array}{l}\text { Acid side } \\
\text { (set 4b) } \\
\end{array}$ & $\begin{array}{c}\text { Alkaline } \\
\text { side } \\
\text { (set 4b) } \\
\end{array}$ & $\begin{array}{c}\text { Entire curve } \\
\text { (set 5a) } \\
\end{array}$ & \\
\hline $\begin{array}{l}\text { Tropical and subtropical } \\
\text { moist broadleaf forests }\end{array}$ & $\begin{array}{c}1.12 \mathrm{E}+04 \\
(1.09 \mathrm{E}+04 ; 1.16 \mathrm{E}+04)\end{array}$ & $\begin{array}{c}-3.05 \mathrm{E}+05 \\
(-3.07 \mathrm{E}+05 ;-3.04 \mathrm{E}+05)\end{array}$ & $9.06 \mathrm{E}+03$ & $-3.04 \mathrm{E}+04$ & $\begin{array}{c}-2.13 \mathrm{E}+04 \\
(-2.14 \mathrm{E}+04 ;-2.12 \mathrm{E}+04)\end{array}$ & $\begin{array}{c}-2.61 \mathrm{E}+04 \\
(-2.64 \mathrm{E}+04 ;-2.55 \mathrm{E}+04)\end{array}$ \\
\hline $\begin{array}{l}\text { Tropical and subtropical } \\
\text { dry broadleaf forests }\end{array}$ & $\begin{array}{c}1.32 \mathrm{E}+05 \\
(1.26 \mathrm{E}+05 ; 1.39 \mathrm{E}+05)\end{array}$ & $\begin{array}{c}-1.48 \mathrm{E}+06 \\
(-1.48 \mathrm{E}+06 ;-1.48 \mathrm{E}+06)\end{array}$ & $7.14 \mathrm{E}+04$ & $-3.64 \mathrm{E}+05$ & $\begin{array}{c}-2.93 \mathrm{E}+05 \\
(-2.95 \mathrm{E}+05 ;-2.91 \mathrm{E}+05)\end{array}$ & $\begin{array}{c}-1.07 \mathrm{E}+05 \\
(-9.98 \mathrm{E}+04 ;-8.35 \mathrm{E}+04)\end{array}$ \\
\hline $\begin{array}{l}\text { Tropical and subtropical } \\
\text { grasslands, savannas and } \\
\text { shrublands }\end{array}$ & $\begin{array}{c}5.29 \mathrm{E}+04 \\
(5.12 \mathrm{E}+04 ; 5.47 \mathrm{E}+04)\end{array}$ & $\begin{array}{c}-6.84 \mathrm{E}+05 \\
(-6.85 \mathrm{E}+05 ;-6.85 \mathrm{E}+05)\end{array}$ & $3.20 \mathrm{E}+04$ & $-1.42 \mathrm{E}+05$ & $\begin{array}{c}-1.10 \mathrm{E}+05 \\
(-1.11 \mathrm{E}+05 ;-1.10 \mathrm{E}+05)\end{array}$ & $\begin{array}{c}-1.23 \mathrm{E}+05(-1.23 \mathrm{E}+05 ;- \\
1.21 \mathrm{E}+05)\end{array}$ \\
\hline $\begin{array}{l}\text { Flooded grasslands and } \\
\text { savannas }\end{array}$ & $\begin{array}{c}2.18 \mathrm{E}+05 \\
(1.95 \mathrm{E}+05 ; 2.48 \mathrm{E}+05)\end{array}$ & $\begin{array}{c}-2.41 \mathrm{E}+06 \\
(-2.44 \mathrm{E}+06 ;-2.42 \mathrm{E}+06)\end{array}$ & $1.22 \mathrm{E}+05$ & $-6.19 \mathrm{E}+05$ & $\begin{array}{c}-4.98 \mathrm{E}+05 \\
(-5.10 \mathrm{E}+05 ;-4.83 \mathrm{E}+05)\end{array}$ & $\begin{array}{c}-5.03 \mathrm{E}+05 \\
(-5.33 \mathrm{E}+05 ;-4.71 \mathrm{E}+05)\end{array}$ \\
\hline $\begin{array}{l}\text { Deserts and xeric } \\
\text { shrublands }\end{array}$ & $\begin{array}{c}1.11 \mathrm{E}+05 \\
(1.08 \mathrm{E}+05 ; 1.14 \mathrm{E}+05)\end{array}$ & $\begin{array}{c}-2.17 \mathrm{E}+06 \\
(-2.18 \mathrm{E}+06 ;-2.17 \mathrm{E}+06)\end{array}$ & $4.61 \mathrm{E}+04$ & $-7.74 \mathrm{E}+05$ & $\begin{array}{c}-7.28 \mathrm{E}+05 \\
(-7.31 \mathrm{E}+05 ;-7.25 \mathrm{E}+05)\end{array}$ & $\begin{array}{c}-7.62 \mathrm{E}+05 \\
(-7.65 \mathrm{E}+05 ;-7.60 \mathrm{E}+05)\end{array}$ \\
\hline Mangroves & $\begin{array}{c}2.71 \mathrm{E}+04 \\
(2.50 \mathrm{E}+04 ; 2.97 \mathrm{E}+04)\end{array}$ & $\begin{array}{c}-3.25 \mathrm{E}+05 \\
(-3.27 \mathrm{E}+05 ;-3.27 \mathrm{E}+05)\end{array}$ & $8.58 \mathrm{E}+03$ & $-9.79 E+04$ & $\begin{array}{c}-8.94 \mathrm{E}+04 \\
(-9.03 \mathrm{E}+04 ;-8.80 \mathrm{E}+04)\end{array}$ & $\begin{array}{c}1.88 \mathrm{E}+03 \\
(-1.41 \mathrm{E}+04 ;-7.82 \mathrm{E}+03)\end{array}$ \\
\hline Brazil & $\begin{array}{c}1.14 \mathrm{E}+04 \\
(1.11 \mathrm{E}+04 ; 1.16 \mathrm{E}+04)\end{array}$ & $\begin{array}{c}-5.04 \mathrm{E}+05 \\
(-5.07 \mathrm{E}+05 ;-5.02 \mathrm{E}+05)\end{array}$ & $8.11 \mathrm{E}+03$ & $-1.02 \mathrm{E}+05$ & $\begin{array}{c}-9.37 E+04 \\
(-9.37 E+04 ;-9.36 E+04)\end{array}$ & $\begin{array}{c}-8.89 \mathrm{E}+04 \\
(-8.98 \mathrm{E}+04 ;-8.78 \mathrm{E}+04)\end{array}$ \\
\hline
\end{tabular}




\subsection{Spatial variability of the effect factors}

In addition to providing EFs for the whole country and for the six biomes in Brazil (see Table 4), EFs were also calculated for 45 ecoregions in Brazil (see Table S3, in Electronic Supplementary Material, ESM) to use the large georeferenced species richness database to investigate the spatial variability of effect factors and discuss what the relevant level of spatial differentiation is in a country like Brazil. Table 4 shows significant variations of areaweighted EFs from $-2.13 \mathrm{E}+04$ to $-7.28 \mathrm{E}+05$ for total species and from $1.88 \mathrm{E}+03$ to 7.62E +05 for range-restricted species at biome level, while Table S3 and Figure 3 show EFs variations from $5.69 \mathrm{E}+04$ to $-3.13 \mathrm{E}+06$ for total species and from $5.16 \mathrm{E}+04$ to $-1.20 \mathrm{E}+06$ for range-restricted species at ecoregion level. Having EFs in fine resolutions thus helps to better understand the effects that soil $\mathrm{pH}$ changes may have on plant diversity, since variations in species richness distribution observed at the ecoregion level may no longer be visible at the scale of biomes or the whole country (Crespo-Mendes et al. 2018).

No consistent pattern was found in the distribution of EFs of ecoregions within the biome to which they belong. The variability of species richness distributions across the grouped ecoregions determined in Crespo-Mendes et al. (2018) is reflected in the EFs presented in Figure 4, with the EFs at the biome level and the spread of EFs for the subordinated ecoregions around it. The number of ecoregions that each biome comprises is not a good predictor of the range of variation around the biome EF. Tropical and subtropical moist broadleaf forests is the biome with by far the largest number of ecoregions (34), and it does have the broadest range of ecoregion EFs both for all species and for range-restricted species. The other five Brazilian biomes have considerably fewer ecoregions (between one and six) but the biome Flooded grasslands and savannas, a biome with only two ecoregions, shows a wide range of ecoregion EFs, in contrast to Mangroves - also a biome with only two ecoregions, as observed in Figure 4. There is poor correspondence between patterns observed for all species and for range-restricted species. For two ecoregions (Caqueta moist forests and Dry Chaco) it was not possible to determine an EF since these ecoregions could not be described by the regression model (data not shown, Crespo-Mendes et al. 2018).

To define at which geographical level the EF should be determined (i.e. at country, biome or ecoregion level), other elements that compose the impact characterization for terrestrial acidification should be considered. The level of spatial differentiation of a characterization model also relies on the spatial resolution adopted by the atmospheric fate models due to the 
source-receptor relationship that the fate factors (FF) represent (i.e. climatic conditions and mechanisms from the emission of acidifying substances to their deposition (Roy et al. 2012a)) and on the exposure models, which express environmental conditions of the receiving environment through the exposure factors (XF) ). LC-Impact, Impact World+ and ReCiPe 2016 methodologies currently have adopted worldwide $2^{\circ} \times 2.5^{\circ}$ grid resolution fate and exposure factors developed by Roy et al. (2012a, b). Considering that (i) areas of the ecoregions in Brazil vary from 126 to $1895808 \mathrm{~km}^{2}$ and (ii) 29 out of 47 ecoregions have an area larger than the grid size used in the fate and exposure factor models (assumed to be a maximum of $61738 \mathrm{~km}^{2}$ to regions close to the equator), the EF at ecoregion level should be preferred since they show how EFs vary at a smaller scale and reflect the variability that is unknown when we operate at biome level (see Figure 4). In cases where it is not possible to determine an EF at the ecoregion level, we recommend as default to use the EF of the biome to which the ecoregion belongs. Moreover, the use of EFs determined at biome level is also recommended for countries composed mostly of ecoregions with an area smaller than the $2^{\circ} \times 2.5^{\circ}$ grid resolution used for the FF and $\mathrm{XF}$, as these EFs are a good proxy of the areaweighted average of the ecoregion EFs (see Table 5).

At the country level, the $\mathrm{EF}_{\mathrm{aw}}$ based on the SR curve for whole Brazil $\left(\mathrm{EF}_{\mathrm{aw}}=-9.37 \mathrm{E}+04\right.$ PNOF.(mol H $\left.\mathrm{H}^{+} \mathrm{L}^{-1}\right)^{-1}$, see Table 4) can also be used as a proxy of the $\mathrm{EF}_{\mathrm{aw}}$ based on the area-weighted average of the biome $\mathrm{EF}_{\mathrm{aw}}$ 's for biomes inside the country $\left(\mathrm{EF}_{\mathrm{aw}}=-1.19 \mathrm{E}+05\right.$ PNOF.(mol H${ }^{+}$. $\left.\mathrm{L}^{-1}\right)^{-1}$ ), being recommended if a country-specific effect factor is needed.
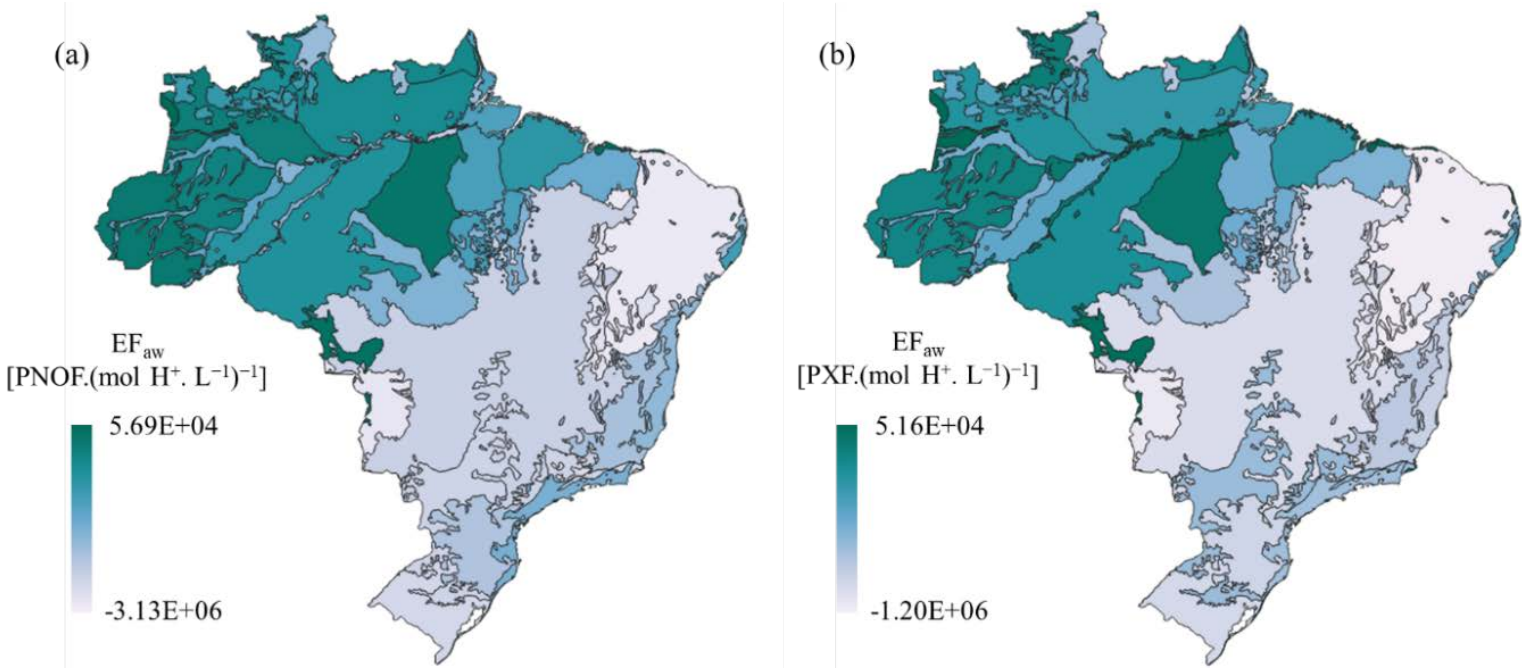

Figure 3. Area-weighted effect factors $\left(\mathrm{EF}_{\mathrm{aw}}\right)$ for ecoregions in Brazil: (a) $\mathrm{EF}_{\mathrm{aw}}$ [PNOF.(mol $\left.\mathrm{H}^{+} . \mathrm{L}^{-1}\right)^{-1}$ ] for all species and (b) $\mathrm{EF}_{\mathrm{aw}}\left[\mathrm{PXF}\right.$. $\left.\left(\mathrm{mol} \mathrm{H}^{+} . \mathrm{L}^{-1}\right)^{-1}\right]$ for range-restricted species. 


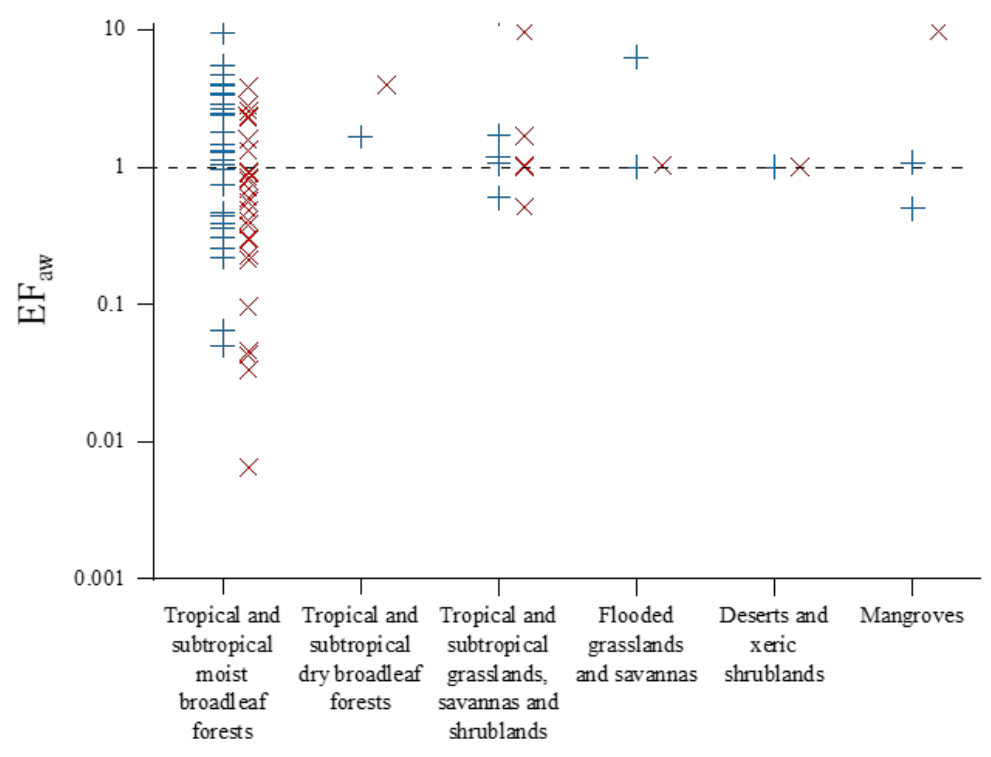

Figure 4. Overview of $\mathrm{EF}_{\mathrm{aw}}\left[\mathrm{PNOF} .\left(\mathrm{mol} \mathrm{H} \mathrm{H}^{+} . \mathrm{L}^{-1}\right)^{-1}\right.$ ] for ecoregions normalized against the $\mathrm{EF}_{\mathrm{aw}}$ of the biome to which they belong, for all species (cross $(+)$ ) and for range-restricted species (cross $(\mathrm{x})$ ). Dotted line represent the $\mathrm{EF}_{\mathrm{aw}}$ at biome level. An overview of $\mathrm{EF}_{\mathrm{aw}}$ calculated for the acid side and the alkaline side of the SR curve separately is presented in Figure S1, ESM.

Table 5. Comparison for biomes between $\mathrm{EF}_{\mathrm{aw}}\left[\mathrm{PNOF} .\left(\mathrm{mol} \mathrm{H} \mathrm{H}^{+} \cdot \mathrm{L}^{-1}\right)^{-1}\right.$ ] based on the biome SR curves and $\mathrm{EF}_{\mathrm{aw}}\left[\mathrm{PNOF}\right.$. $\left(\mathrm{mol} \mathrm{H} \mathrm{H}^{+} . \mathrm{L}^{-1}\right)^{-1}$ ] based on the area-weighted average of the ecoregion $\mathrm{EF}_{\mathrm{aw}}$ 's for ecoregions inside the biome.

\begin{tabular}{lccc}
\hline \multicolumn{1}{c}{ Biome } & $\begin{array}{c}\text { (I) } \\
\text { EF based on SR } \\
\text { curve from Table 4 } \\
{\left[\text { PNOF. }\left(\mathrm{mol} \mathrm{H}^{+} . \mathrm{L}^{-1}\right)^{-1}\right]}\end{array}$ & $\begin{array}{c}\text { (II) } \\
\text { EF based on area- } \\
\text { weighted ecoregion } \\
\text { EFs } \\
\left.\left[\text { PNOF.(mol H} . \mathrm{L}^{-1}\right)^{-1}\right]\end{array}$ & $\begin{array}{c}\text { II/I } \\
\text { Ratio }\end{array}$ \\
\hline Tropical and subtropical moist broadleaf forests & $-2.13 \mathrm{E}+04$ & $-2.83 \mathrm{E}+04$ & 1.33 \\
Tropical and subtropical dry broadleaf forests & $-2.93 \mathrm{E}+05$ & $-3.01 \mathrm{E}+05$ & 1.03 \\
$\begin{array}{l}\text { Tropical and subtropical grasslands, savannas and } \\
\text { shrublands }\end{array}$ & $-1.10 \mathrm{E}+05$ & $-1.18 \mathrm{E}+05$ & 1.07 \\
Flooded grasslands and savannas & $-4.98 \mathrm{E}+05$ & $-5.07 \mathrm{E}+05$ & 1.02 \\
Deserts and xeric shrublands & $-7.28 \mathrm{E}+05$ & $-7.28 \mathrm{E}+05$ & 1.00 \\
Mangroves & $-8.94 \mathrm{E}+04$ & $-8.07 \mathrm{E}+04$ & 0.90 \\
\hline
\end{tabular}




\subsection{Potentially Extinct Fraction (PXF) as a complementary metric for terrestrial acidification in LCIA}

Range-restricted species richness as a potential complementary indicator of biodiversity was integrated into the effect factors through the use of the Potentially Extinct Fraction (PXF) of species (set 5b, Section 2.4). PXF curves are narrower than PNOF curves for all biomes in Brazil, in particular for the biome Mangroves (see Figure 5), reflecting that range-restricted species occur across a smaller range of soil $\mathrm{pH}$ values. In terms of optimum $\mathrm{pH}$, i.e. the $\mathrm{pH}$ value at which the highest number of range-restricted species occur ( $\mathrm{PXF}=0)$, two behaviors are observed at the biome level. Some biomes have the same optimum $\mathrm{pH}$ value for all species and for range-restricted species. This is the case for Tropical and subtropical moist broadleaf forests and Tropical and subtropical grasslands, savannas and shrublands. The remaining biomes present a slight displacement of the PXF curve towards more alkaline $\mathrm{pH}$, showing an optimum $\mathrm{pH}$ for range-restricted species that is higher than the optimum $\mathrm{pH}$ for the entire list of species. For the first group of biomes, relying the EF on PNOF or PXF brings similar results since the maximum number of species in the biome coincides in terms of soil $\mathrm{pH}$ with the maximum number of range-restricted species. For the second group of biomes where the PXF curve is displaced relative to the PNOF curve, changes in the soil caused by acidifying substances may be associated with a decrease in the number of rangerestricted species that is not necessarily reflected by a decrease in the total species richness. These two behavior patterns observed at biome level were also observed at ecoregion level (see Figure S1, ESM). For most ecoregions (mainly those that compose the biomes Tropical and subtropical moist broadleaf forests and Tropical and subtropical grasslands, savannas and shrublands) the optimum $\mathrm{pH}$ for range-restricted species is lower than the optimum $\mathrm{pH}$ for the entire list of species (Crespo-Mendes et al. 2018), causing a slight displacement of the PXF curves towards acid $\mathrm{pH}$.

Since PNOF curves are often not a good proxy for PXF curves, the two should be considered as complementary metrics to assess the effects of terrestrial acidification on biodiversity. The first focusing on the total quantity of species of a region and the last prioritizing the conservation of unique species, thus preventing the extinction of potentially endemic species of Brazil or, possibly, of the world. To support the application of the PXF concept in the LCIA methodologies, EFs were calculated following the scenario recommended in Section 3.2. Area-weighted EF for the entire curve at country, biome and ecoregion levels are 
presented in Table 4 and Table S3 (ESM), respectively. For six ecoregions (see Table S3, ESM), for which EFs were not attributed due to lack of data for their regression model (Crespo-Mendes et al. 2018), it is recommended to use the EF of the biome to which they belong.
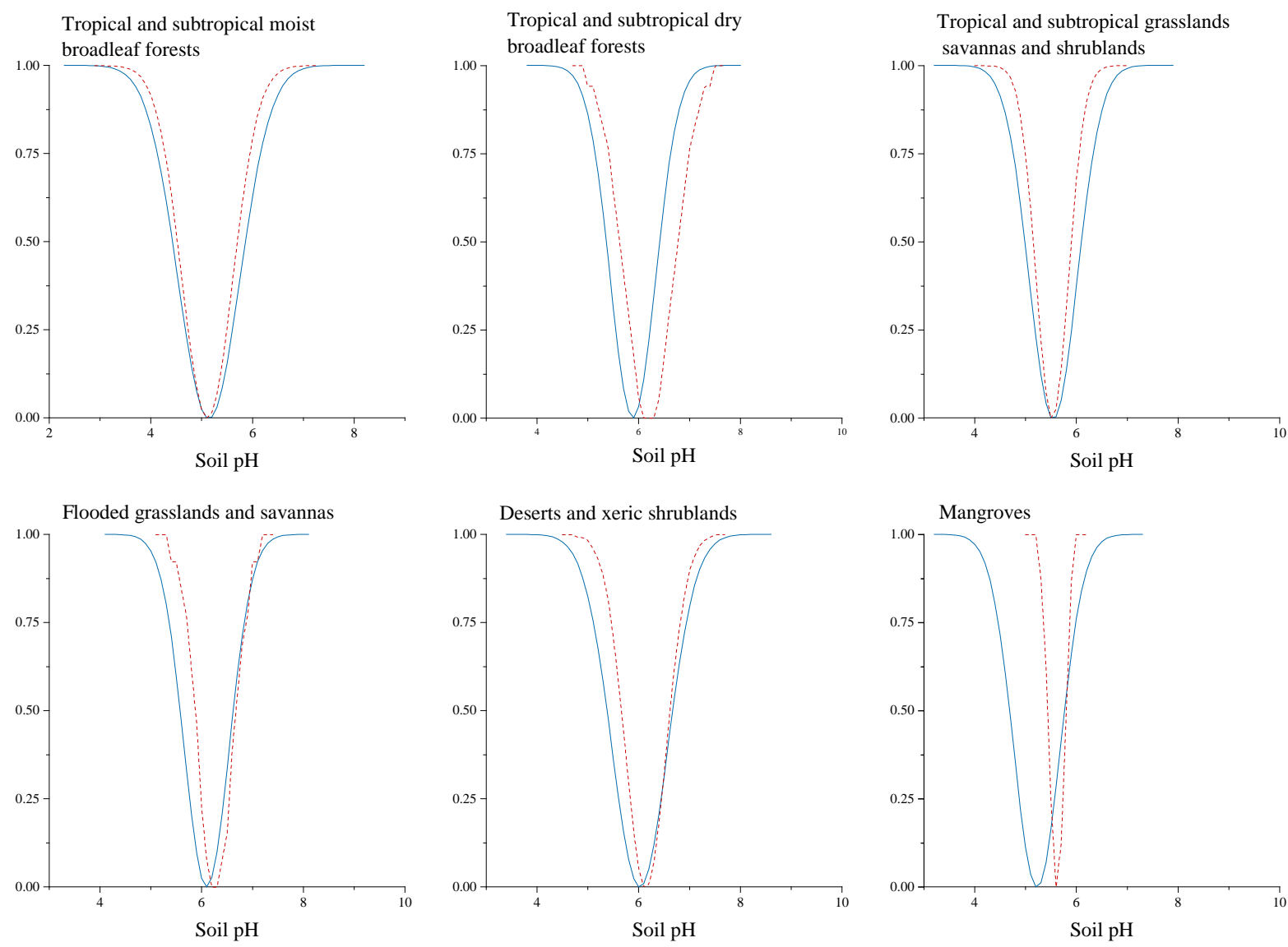

Figure 5. Potentially not occurring fractions (PNOF) of species (thick curve) and Potentially Extinct Fraction (PXF) of species (dotted curve) per biome (6) in Brazil. More PNOF and PXF curves at the country, biome and ecoregion levels in Brazil are presented in Figures S2, S3 and S4 (ESM), respectively.

\subsection{Uncertainties}

Sources of uncertainty in this study stem mainly from the data sets used to build the species richness curves as a function of soil pH. Crespo-Mendes et al. (2018) have identified the main sources as: inaccurate georeferencing of plant occurrences, errors in taxonomic identification, classification and/or selection of plant species with terrestrial habitat and estimates of soil $\mathrm{pH}$ values. Initiatives taken to minimize their effects are detailed in Crespo- 
Mendes et al. (2018). The first three sources refer directly to the botanical inventory used to represent the species richness of Brazil. However, given the large data set, the high number of species occurrences for all biomes and most ecoregions in Brazil these sources of uncertainty are assumed to be negligible (Crespo-Mendes et al. 2018). Uncertainties related to the statistical modeling of the distribution of soil $\mathrm{pH}$ values are the most relevant for this study since $\mathrm{pH}$ is used as an indicator of soil acidity. Considering that the width of the prediction interval used to propagate the uncertainties in models presents the same variation for all regions, there is a same probability that the correct value is higher or lower than the average one used in this study. Thus, it is not expected a significant influence on species richness curves (Crespo-Mendes et al. 2018).

Regarding the uncertainties introduced by the modeling of the PNOF and PXF curves, the parameters provided by the lognormal regression analysis are used to estimate the $95 \%$ confidence interval and propagate them to the effect factor values. These EFs with uncertainty ranges can be used for comparisons with existing factors, e.g. EFs by Azevedo et al. (2013). At country and biome levels, the uncertainty ranges related to the area-weighted EFs are lower than 3\% (see Table 4) and for most ecoregions the uncertainty ranges are lower than $10 \%$, as shown in Table S4, ESM.

\section{CONCLUSIONS AND RECOMMENDATIONS}

Effect factors to assess terrestrial acidification in LCIA are provided for all six biomes and 45 ecoregions in Brazil based on a representative data set of approximately 30000 terrestrial plant species. Comparisons with previous studies (Azevedo et al. 2013; Roy et al. 2014) show that using more comprehensive data sets avoids underestimating the species richness, thus yielding more accurate EFs. Additionally, having EFs in refined spatial resolutions such as ecoregions allows us to observe variations in the species richness distribution that are not necessarily observed at the country or biome level. Besides providing EFs that are compatible with those adopted by the most recent LCIA methodologies, we also provide area-weighted EFs for the whole country, biomes and ecoregions that enable the consideration of both acid and alkaline sides of the species richness curves. We recommend these latter EF values for application in LCIA of terrestrial acidification. 
The metrics to assess damages from terrestrial acidification are presented as key points of this study. Species richness is the metric that is generally used to represent damage to ecosystems in current LCIA methods at endpoint level, and previous effect factor models have focused exclusively on the acid side of the species richness or PNOF curves for determination of the effect factor (Azevedo et al. 2013; Roy et al. 2014). This approach, which has been adopted for terrestrial acidification, is based on the species sensitivity distributions (SSD) method currently used for ecotoxicological impact assessment in LCIA (see Section 3.3). Our recommended area-weighted effect factors $\left(\mathrm{EF}_{\mathrm{aw}}\right)$ however do not consider the protons from acidification as toxic agents, and the two sides of the SR curves are thus included in its calculation. As visible from Tables 4 and S3, acidification $\mathrm{EF}_{\mathrm{aw}}$ values for Brazil at biome and ecoregion levels are mostly negative indicating that soils in Brazil are too alkaline ("under-acidified”) and that acidification overall brings benefits to plant species since lowering of soil $\mathrm{pH}$ will be associated with a higher species richness. However, biodiversity is inadequate as a sole indicator of ecosystem health since decreasing or increasing the number of species as a result of soil $\mathrm{pH}$ variance does not automatically reflect, for example, the functions of the species in the ecosystem (i.e. functional diversity). By focusing on species richness only, a number of species with unique functions in the ecosystem eventually can be lost, even if the number of species increases. The current situation may be improved by introducing further spatial differentiation to capture the differences in EFs among ecoregions inside a given biome that receive acid inputs, but the chosen level of spatial differentiation should respect the size of the deposition area for the emission.

An improvement potential also lies in introduction of the range-restricted species richness as a complementary metric - expressed as PXF - to represent the conservation of species that are unique to ecoregions in Brazil and could cause irreversible damage to the environment if lost. This is a relevant metric for the assessment of species vulnerability that could be integrated into terrestrial acidification characterization models. Another key point of the prevailing method for effect factor assessment, also applied in this study, concerns the lack of proven causality in the relation between soil $\mathrm{pH}$ and species occurrence. The work of CrespoMendes et al. (2018) and the resulting species richness curves demonstrate a very strong correlation between these two variables, but it does not prove that soil $\mathrm{pH}$ is the driver for the species occurrence. Many other environmental factors are potentially influential (nutrients, light, local climate, etc.) and although the correlations are strong, there may confounding factors like the fact that the soils with the most frequent $\mathrm{pH}$ values represent the largest 
surface of the region and are hence also the soils most likely to be observed and have their plant species reported in the database. All these above findings therefore point out to the inadequacy of species richness to comprehensively represent damage to ecosystems and call for complementary indicators.

Overall, based on the methodological elements developed in this study, that rely on the use of comprehensive databases such as the botanical inventory reported by Crespo-Mendes et al. (2018), we recommend the integration into LCIA methodologies of area-weighted effect factors that consider the entire species richness distribution curves (both acid and alkaline parts of the curves) and the new complementary metric Potentially Extinct Fraction (PXF) of species, which could be used for characterizing terrestrial acidification as well as other impact categories. To do so, further research is however needed to expand such work to other regions than Brazil and reach a complete global coverage, thus enabling to combine the EF with atmospheric fate factors and soil exposure factors to derive characterization factors to be used in LCIA.

\section{ACKNOWLEDGEMENTS}

Funding: This work was supported by the CAPES Foundation, Ministry of Education of Brazil, Process number 9365/13-3.

\section{REFERENCES}

Azevedo LB, van Zelm R, Hendriks AJ, Bobbink R, Huijbregts MA (2013) Global assessment of the effects of terrestrial acidification on plant species richness. Environmental pollution, 174, 10-15.

Crespo-Mendes N, Laurent A, Bruun HH, Hauschild MZ (2018) Relationships between plant species richness and soil $\mathrm{pH}$ at the level of biome and ecoregion in Brazil. Ecological Indicators (accepted for publication). 
de Baan L, Mutel CL, Curran M, Hellweg S, Koellner T (2013) Land Use in Life Cycle Assessment: Global Characterization Factors Based on Regional and Global Potential Species Extinction. Environ. Sci. Technol. 47, 16, 9281-9290.

EC-JRC - European Commission-Joint Research Centre - Institute for Environment and Sustainability (2010) International Reference Life Cycle Data System (ILCD) Handbook Framework and Requirements for Life Cycle Impact Assessment Models and Indicators. First edition. March 2010. Publications Office of the European Union, Luxemburg.

EC-JRC (2011) International Reference Life Cycle Data System (ILCD) Handbook Recommendations for Life Cycle Impact Assessment in the European context. First edition. November 2011. Publications Office of the European Union, Luxemburg.

Forzza, R.C., Baumgratz, J.F.A., Bicudo, C.E.M., Canhos, D.A.L., Carvalho, A.A., Coelho, M.A.N., Costa, A.F., Costa, D.P., Hopkins, M.G., Leitman, P.M., Lohmann, L.G., Lughadha, E.N., Maia, L.C., Martinelli, G., Menezes, M., Morim, M.P., Peixoto, A.L., Pirani, J.R., Prado, J., Queiroz, L.P., Souza, S., Souza, V.C., Stehmann, J.R., Sylvestre, L.S., Walter, B.M.T., Zappi, D.C., 2012. New Brazilian Floristic List Highlights $\begin{array}{llll}\text { Conservation } & \text { Challenges. } & \text { BioScience. } & \text { 39-45. }\end{array}$ https://doi.org/10.1525/bio.2012.62.1.8.

Goedkoop M, Huijbregts MAJ, Heijungs R, De Schryver A, Struijs J, Van Zelm R (2009) ReCiPe 2008: a life cycle impact assessment method which comprises harmonised category indicators at the midpoint and the endpoint level. Ministry of Housing, Spatial Planning and the Environment (VROM), Amersfoort, The Netherlands.

Guinée JBE, Gorrée M, Heijungs R, Huppes G, Kleijn R, De Koning A, Van Oers L, Wegener Sleeswijk A, Suh S, Udo de Haes HA, De Bruijn JA, Van Duin R, Huijbregts MAJ (2002) Handbook on life cycle assessment: operational guide to the ISO standards. SeriesL eco-efficiency in industry and science. Kluwer Academic Publishers, Dordrecht.

GBIF: The Global Biodiversity Information Facility (2017) What is GBIF? Available via http://www.gbif.org/what-is-gbif. 
Hauschild M, Wenzel H (1998) Environmental assessment of products vol 2: scientific background. Chapman \& Hall/Kluwer Academic Publishers, London/Hingham, 1997. ISBN 0412-80810-2.

Hayashi K, Okazaki M, Itsubo N, InabaA(2004) Development of damage function of acidification for terrestrial ecosystems based on the effect of aluminium toxicity on net primary production. Int J Life Cycle Assess 9:13-22.

Hengl, T., de Jesus, J.M., MacMillan, R.A., Batjes, N.H., Heuvelink, G.B.M., Ribeiro, E., Samuel-Rosa, A., Kempen, B., Leenaars, J.G.B., Walsh, M.G., Gonzalez, M.R., 2014. SoilGrids1km - Global Soil Information Based on Automated Mapping. PLoS ONE. 9, e105992. doi:10.1371/journal.pone.0105992.

Heijungs R, Guinee JB, Huppes G, Lankreijer RM, Udo de Haes HA, Wegener Sleeswijk A, Ansems AMM, Eggels PG, Van Duin R, De Goede HP (1992) Environmental life cycle assessment of products: guide and backgrounds. Centre of Environmental Science, University, Leiden, Leiden.

Huijbregts MAJ, Steinmann ZJN, Elshout PMF, Stam G, Verones F, Vieira M, Zjip M, Hollander A, van Zelm R (2017) ReCiPe2016: a harmonised life cycle impact assessment method at midpoint and endpoint level. Int J Life Cycle Assess 22:138-147.

IMPACT Wolrd+ (2018) Available via http://www.impactworldplus.org/en/index.php

Kemna R, Van Elburg M, Li W, Van Holsteijn R (2005) MEEuP methodology report, final. 28 Nov 2005. VHK for European Commission, Brussels.

Larsen HF, Hauschild MZ (2007) Evaluation of Ecotoxicity Effect Indicators for Use in LCIA. Int J Life Cycle Assess 12: 24-33.

LC-Impact: A spatially differentiated Life Cycle Impact Assessment method (2018) Available via http://www.lc-impact.eu/

Norris GA (2003) Impact characterization in the tool for the reduction and assessment of chemical and other environmental impacts; methods for acidification, eutrophication and ozone formation. J Ind Ecol 6(3-4):79-101. 
Olson DM, Dinerstein E, Wikramanayake ED, Burgess ND, Powell GVN, Underwood EC, D'Amico JA, Itoua I, Strand HE, Morrison JC, Loucks CJ, Allnutt TF, Ricketts TH, Kura Y, Lamoreux JF, Wettengel WW, Hedao P, Kassem KR (2001) Terrestrial ecoregions of the world: a new map of life on Earth. Bioscience 51(11):933-938.

Pennington DW, Payet J, Hauschild MZ (2004) Aquatic Ecotoxicological Indicators In LifeCycle Assessment. Environ. Toxicol. Chem. 23: 1796-1807.

Potting J, Schöpp W, Blok K, Hauschild M (1998) Site-dependent life-cycle impact assessment of acidification. J Ind Ecol 2(2):63-87.

Roy PO, Huijbregts M, Deschênes L, Margni M (2012a) Spatially-differentiated atmospheric source-receptor relationships for nitrogen oxides, sulfur oxides and ammonia emissions at the global scale for life cycle impact assessment. Atmos Environ 62:74-81.

Roy PO, Deschenes L, Margni M (2012b) Life cycle impact assessment of terrestrial acidification: modeling spatially explicit soil sensitivity at the global scale. Environ Sci Technol 46 (15):8270-8278.

Roy PO, Azevedo LB, Margni M, van Zelm R, Deschênes L, Huijbregts MAJ (2014) Characterization factors for terrestrial acidification at the global scale: a systematic analysis of spatial variability and uncertainty. Sci Tot Environ 500:270-276.

Scherer L, Pfister S (2016) Global water footprint assessment of hydropower. Renewable Energy, 99, 711-720.

Seppälä J, Posch M, Johansson M, Hettelingh JP (2006) Country-dependent characterization factors for acidification and terrestrial eutrophication based on accumulated exceedance as an impact category indicator. Int J Life Cycle Assess 11(6):403-416.

Steen B (1999) Asystematic approach to environmental priority strategies in product development (EPS). Version 2000 - models and data of the default method. Chalmers University of Technology, Göteborg.

Udo de Haes HA, Finnveden G, Goedkoop MJ, Hauschild M, Hertwich E, Hofstetter P, Jolliet O, Klöpfer W, Krewitt W, Lindeijer E, Müller-Wenk R, Olsen SI, Pennington DW, 
Potting J, Steen B (2002) Life-cycle impact assessment: striving towards best practice. SETAC Press, Pensacola, Florida.

Van Zelm R, Huijbregts MAJ, Van Jaarsveld JA, Reinds GJ, De Zwart D, Struijs J, Van de Meent D (2007) Time horizon dependent characterization factors for acidification in lifecycle assessment based on forest plant species occurrence in Europe. Environ Sci Technol 41:922-927.

Van Zelm R, Roy PO, Hauschild MZ, Huijbregts MAJ (2015) Acidification. In: Hauschild, M., Huijbregts, M. (eds) Life Cycle Impact Assessment. LCA Compendium - The Complete World of Life Cycle Assessment. Springer, Dordrecht.

Verones F, Saner D, Pfister S, Baisero D, Rondinini C, Hellweg S (2013) Effects of Consumptive Water Use on Biodiversity in Wetlands of International Importance. Environ. Sci. Technol. 47, 21, 12248-12257.

Verones F, Huijbregts MAJ, Chaudhary A, de Baan L, Koellner T, Hellweg S (2015) Harmonizing the Assessment of Biodiversity Effects from Land and Water Use within LCA. Environ. Sci. Technol. 49 (6), 3584-3592.

Wenzel H, Hauschild M, Alting L (1997) Environmental assessment of products vol 1: methodology, tools and case studies in product development. Chapman \& Hall/Kluwer Academic Publishers, London/Hingham, 1997. ISBN $\quad 0 \quad 412 \quad 80800$. 

Mendes N.C., Laurent A., Hauschild M.Z., 2018. Effect factors of terrestrial acidification in Brazil for use in Life Cycle Impact Assessment. International J ournal of Life Cycle Assessment. https://doi.org/10.1007/s11367-018-1560-7. 